\title{
Chemical composition, proximate and phytochemical analysis of Irvingia gabonensis and Irvingia wombolu peels, seed coat, leaves and seeds
}

\author{
Nkoli Marynnn MGBEMENA* ${ }^{1}$ Ifenna ILECHUKWU, ${ }^{2}$ Felicia Uchechukwu \\ OKWUNODOLU, ${ }^{1}$ Joe-Vera Ogugua CHUKWURAH, ${ }^{2}$ and Isioma Blessing LUCKY ${ }^{2}$ \\ ${ }^{1}$ Department of Chemistry, Michael Okpara University of Agriculture Umudike, Abia State Nigeria \\ ${ }^{2}$ Department of Industrial Chemistry, Madonna University Nigeria
}

\begin{abstract}
The study focused on the proximate, minerals and phytochemical analysis of the leaves, seeds, seed coats and peels of Irvingia gabonensis and Irvingia wombolu from Uli in Anambra State Nigeria. The minerals concentrations (Ca, $\mathrm{Zn}, \mathrm{Fe}, \mathrm{Mg}$ ) were determined with atomic absorption spectrometer (AAS) while sodium was determined with flame photometer. The trend in mineral concentration was $\mathrm{Mg}>\mathrm{Na}>\mathrm{Ca}>\mathrm{Zn}>\mathrm{Fe}$. Phytochemical analysis revealed the presence of alkaloids, flavonoids and saponins in both species. The proximate analysis showed that the carbohydrates contents in the leaves and seeds of $I$. wombolu were $51.7 \pm 1.3 \%$ and $57.6 \pm 0.31 \%$ respectively, while the moisture content of the peels was $34.0 \pm 0.20 \%$. The results of this study showed that the leaves, seeds, seed coats and peels of the two Irvingia species are potential sources of food nutrients and phytochemicals, and therefore should be maximally utilized.
\end{abstract}

Keywords: Irvingia species; proximate analysis; mineral analysis; phytochemical analysis.

\section{Introduction}

Irvingia species are economically important trees that grow in the wild forests of most West and Central African countries [1]. There are about seven species of Irvingia in Africa, i.e. Irvingia excels and Irvingia grandiofolia (Central Africa), Irvingia gabonensis, Irvingia robur and Irvingia smithii (West and Central Africa), Irvingia wombolu (West Africa) and Irvingia malayana (Southeast Africa). Of these species, two are predominantly found in Nigeria (Irvingia gabonensis and Irvingia wombolu). Irvingia spp. is commonly called African/bush/wild mango because of their mango like fruits $[2,3]$. The fruits are ellipsoidal, $4-7 \mathrm{~cm}$ long, with a fleshy mesocarp, green when unripe and yellow or light orange when ripe [4]. The pulp, kernel and fruit are edible both by man and animals, although bitter and acrid, with turpentine flavor [5]. The fruits are rich in oil and can be used in making bread, chocolate, cheese, butter, soap and feed cake. The kernels of the fruits are considered to be the most valuable component for various reasons. They are rich source of fat, oil and protein and are used widely as condiments in thickening of sauce [2]. Irvingia gabonensis and Irvinga wombolu are similar and are often difficult to differentiate from herbarium specimens alone [1]. However, the two may be distinguished by edibility of the fruit mesocarp. Harris [1] also mentioned the density of fibers in the mesocarp, the amount of mucilage in the cotyledons, the size of the endosperm, the height of first branching, the disc shape in unfertilized flowers and the shape of the tree as diagnostic characters. Irvingia gabonensis fruit can be eaten as fruit. The sweet pulp can be juiced or used for making smoothie, jelly, jam and wine. The seeds can be pressed for vegetable oil or margarine. The dried dika nut seeds can be ground and used for preparing "ogbono" soup, stew, chocolate and dika bread. Ngodi et al. [3] opined that ogbono seed is capable of reducing fasting blood glucose levels in obese beings. Furthermore, a study evaluated the antidiabetic properties of Irvingia gabonensis leaf and bark extracts on alloxan induced diabetic rats [6]. The study showed that the aqueous extracts of leaf and bark of Irvingia gabonensis had more anti-diabetic activity than ethanolic extracts. Okoro [7, 8] screened the water and ethanol extracts of the powdered stem bark to ascertain the analgesic effects of this fruit. The results were further compared with standard analgesic drugs. The study suggests that the water extract has analgesic effects similar to a narcotic analgesic. Dika nut contains sticky wax (mucilage) that has useful excipient properties for making medicinal tablets. The wax acts as a binding agent during tablets production. Studies reveal that tablets manufactured with bush mango have increased bitterness and reduced tensile strength when compared to gelatin tablets [3]. The study validates that obese patients given Irvingia gabonensis had a significant decrease in low density lipoprotein (LDL) cholesterol, triglycerides, and total cholesterol with an increase in high density lipoprotein (HDL) cholesterol. This suggests that Irvingia gabonensis is suitable for regulating the serum cholesterol levels.

Ekpe et al. [9] support that bacterial and fungal infections can be treated with the methanolic extract of Irvingia gabonensis. The decocted bark can be used in the treatment of diarrhea and dysentery. The bark can also be mixed with palm oil for treating diarrhea. Dika nut fruit can be eaten to improve bowel functioning and for preventing constipation because it is rich in dietary fiber. The powdered kernels can be used as an astringent to soothe burns and reduce bleeding from minor

${ }^{*}$ Corresponding author. E-mail address: nkolimgbemena@gmail.com (Nkoli Marynnn Mgbemena) 
abrasions [10]. The stem of the tree also serves as chewing sticks for cleaning teeth [11]. The plant though being highly explored still lacks sufficient evidences to ascertain the best variety and parts possessing the highest degree of medicinal, nutritive and mineral values. The study therefore aimed at evaluation of the leaves, peels, seeds and seed coats of $I$. wombolu and $I$. gabonensis to ascertain which of these parts has more of the mineral nutrients and phytochemicals.

\section{Experimental}

\subsection{Collection and preparation of samples}

Twenty fresh fruits and $100 \mathrm{~g}$ of leaves of each of Irvingia spp. were plucked from the trees in March, at Uli in Anambra State, Nigeria and carried to the laboratory for analysis using polythene bags. Both the fruits and leaves were washed thoroughly to remove sand particles and debris. The two species were identified by a botanist in the Department of Pharmacognosy, Faculty of Pharmacy, Madonna University Nigeria. The seed coats and peels were separated from the fleshy pulp with knife and air dried under a shade for three days. This was done to exclude direct sunlight in other to prevent the active constituents from being degraded. The dried leaves, peels, seeds and seed coats were milled separately with blender and stored in airtight containers at $4{ }^{\circ} \mathrm{C}$ until required for analysis.

\subsection{Proximate analysis}

Samples were analyzed for percentage moisture, ash, crude lipid, crude protein, carbohydrates and crude fiber using AOAC 2016 methods [12]. Moisture was determined by drying to constant weight while protein was determined using Kjeldahl method. Ash content was determined with Loss-on-Ignition method.

\subsection{Mineral analysis}

$1 \mathrm{~g}$ of each sample was digested with $10 \% \mathrm{HNO}_{3}$ after ashing. The sample was filtered after digestion and the filtrate made up to $100 \mathrm{~mL}$ with distilled deionized water. Atomic Absorption Spectrometer (Buck Scientific East Norwalk, USA) was used to determine the concentration of $\mathrm{Fe}, \mathrm{Mg}, \mathrm{Zn}$, and $\mathrm{Ca}$, while Flame Photometry (Jenway Ltd, Dunmow Essex UK) was used for the determination of $\mathrm{Na}$.

\subsection{Phytochemical analysis}

Phytochemical analysis was done on two extracts (methanolic and aqueous extracts) of the powdered samples. $10 \mathrm{~g}$ of each powdered samples were transferred into a conical flask and the extracting solvent (90\% methanol) was added. The mixture was shaken vigorously to ensure proper mixing between the samples and the solvent. It was then kept for 24 hours after which it was sieved, and the filtrate stored in the refrigerator prior to analysis. Aqueous extraction followed the same procedure with distilled water as the extracting solvent.
Qualitative phytochemical analysis of the extracts was carried out using the methods of Harbone [13] and Abdulrahman et al. [14]. Wagner's reagent and Meyer's reagent were used to test for alkaloids, while ferric chloride was used to test for flavonoids. Salkowski test was used to determine steroids while Frothing test was used for the saponins and the terpenoids were determined with sulfuric acid and chloroform while glycosides were determined using Keller-Killian test [15].

\section{Results and discussion}

Table 1 shows the proximate composition of Irvingia gabonensis and Irvingia wombolu leaves, peels, seeds and seed coats samples. The moisture contents in seeds, leaves, peels and seed coats of Irvingia gabonensis were $1.4 \pm 0.41 \%, 22.2 \pm 0.11 \%, 38.7 \pm 0.01 \%$, and $57.6 \pm 0.90 \%$ respectively. In Irvingia wombolu, the moisture contents were $\quad 6.5 \pm 0.41 \%, \quad 9.4 \pm 0.02 \% \quad 9.8 \pm 0.14 \% \quad$ and $13.24 \pm 0.13 \%$ in seeds, leaves, seed coats and peels respectively. Irvingia gabonensis had higher moisture content than Irvingia wombolu. High moisture content in fruits is an index of its water activity, measure of stability and susceptibility to microbial contamination [15]. I. wombolu is less susceptible to microbial contamination given the less moisture content. The ash contents in peels and seed coats of I. gabonensis were $0.75 \pm 0.11 \%$ and $6.8 \pm 0.12 \%$ respectively. The leaves and seed coats had the same ash contents of $2.4 \pm 0.12 \%$. The ash content in I. wombolu were $6.3 \pm 0.20 \%$, $14.5 \pm 0.11 \%, 22.9 \pm 0.04 \%$, and $34.00 \pm 0.20 \%$ in seeds, seed coats, leaves and peels respectively. Ash content in this work was higher than that of Ekundayo et al. [16] where ash ranged from $3.30 \%$ to $2.43 \%$ and that of Adeyeye [17] with ash content of $2.4 \%$ and $2.5 \%$ in $I$. gabonensis and also related to the work of Efosa et al. [18]. Ash content in food is the inorganic residue left after the removal of moisture and organic matter. It provides the measure of the total amount of minerals within a food. The result of this work showed high ash contents in the peels and leaves of I. wombolu and low ash contents in the peels and seed coats of I. gabonensis. Therefore, the peels and leaves of $I$. wombolu should not be discarded or allowed to waste away. I. wombolu showed higher value of crude fat. Dietary fat is the major source of energy. The daily recommended value of not more than 30 calories should not be exceeded to avoid obesity, diabetes and heart diseases. Crude fiber contains indigestible cellulose which helps to absorb water, provide roughage and better functioning of the alimentary system. Protein contents contribute positively to the requirement for biomolecules needed for repair and maintenance of the body tissues as well as synthesis of vital hormones for the body $[19,20]$. The seed of I. gabonensis had the highest carbohydrates content. So by eating the seed of I. gabonensis a lot of energy is acquired.

Table 1. The proximate composition of Irvingia gabonensis and Irvingia wombolu

\begin{tabular}{|c|c|c|c|c|c|c|c|c|}
\hline & \multicolumn{4}{|c|}{ I. gabonensis } & \multicolumn{4}{|c|}{ I. wombolu } \\
\hline Percentage $(\%)$ & Leaves & Peels & Seed & Seed coat & Leaves & Peels & Seed & Seed coat \\
\hline Moisture & $22.2 \pm 0.11$ & $38.7 \pm 0.01$ & $1.4 \pm 0.11$ & $57.6 \pm 0.10$ & $9.4 \pm 0.02$ & $13.24 \pm 0.13$ & $6.5 \pm 0.41$ & $9.8 \pm 0.14$ \\
\hline Ash & $2.4 \pm 0.12$ & $0.75 \pm 0.11$ & $6.8 \pm 0.12$ & $2.4 \pm 0.12$ & $22.9 \pm 0.04$ & $34 \pm 0.20$ & $6.3 \pm 0.20$ & $4.5 \pm 0.11$ \\
\hline
\end{tabular}


Mgbemena et al./ Ovidius University Annals of Chemistry 30 (2019) 65-69

\begin{tabular}{|l|l|l|l|l|l|l|l|l|}
\hline & \multicolumn{4}{|c|}{ I. gabonensis } & \multicolumn{4}{c|}{ I. wombolu } \\
\hline Crude lipid & $2.1 \pm 0.01$ & $1.6 \pm 0.12$ & $7.9 \pm 0.01$ & $1.59 \pm 0.12$ & $3.1 \pm 0.20$ & $1.2 \pm 0.10$ & $37.9 \pm 0.95$ & $2.2 \pm 0.01$ \\
\hline Crude fibre & $11.8 \pm 0.02$ & $19 \pm 0.21$ & $21.6 \pm 0.45$ & $16.7 \pm 0.12$ & $18.1 \pm 0.21$ & $22.5 \pm 0.18$ & $20 \pm 0.18$ & $25.4 \pm 0.11$ \\
\hline Crude protein & $98 \pm 0.11$ & $7.7 \pm 0.12$ & $5.6 \pm 0.20$ & $6.65 \pm 0.11$ & $7.7 \pm 0.01$ & $6.3 \pm 0.01$ & $8.4 \pm 0.20$ & $9.45 \pm 0.01$ \\
\hline
\end{tabular}

Table 2. Mineral composition of Irvingia gabonensis and Irvingia wombolu

\begin{tabular}{|l|l|l|l|l|l|l|c|c|}
\hline & \multicolumn{4}{|c|}{ I. gabonensis } & \multicolumn{4}{c|}{ I. wombolu } \\
\hline Metal (mg/kg): & Leaves & Peels & Seed & Seed coat & Leaves & Peels & Seed & Seed coat \\
\hline Iron & $0.280 \pm 0.02$ & $0.237 \pm 0.01$ & $0.040 \pm 0.02$ & $0.395 \pm 0.00$ & $0.474 \pm 0.00$ & $0.462 \pm 0.01$ & $0.304 \pm 0.02$ & $0.565 \pm 0.01$ \\
\hline Magnesium & $41.138 \pm 0.00$ & $4.911 \pm 0.01$ & $27.944 \pm 0.02$ & $4.176 \pm 0.01$ & $20.528 \pm 0.01$ & $24.750 \pm 0.00$ & $11.717 \pm 0.02$ & $7.501 \pm 0.01$ \\
\hline Zinc & $3.829 \pm 0.02$ & $2.984 \pm 0.01$ & $2.937 \pm 0.02$ & $3.466 \pm 0.01$ & $2.985 \pm 0.01$ & $4.298 \pm 0.02$ & $1.937 \pm 0.02$ & $3.188 \pm 0.01$ \\
\hline Sodium & $8.977 \pm 0.02$ & $5.263 \pm 0.01$ & $7.297 \pm 0.02$ & $5.372 \pm 0.02$ & $6.373 \pm 0.02$ & $10.372 \pm 0.01$ & $4.992 \pm 0.02$ & $9.466 \pm 0.02$ \\
\hline Calcium & $4.222 \pm 0.02$ & $3.928 \pm 0.01$ & $3.278 \pm 0.01$ & $4.992 \pm 0.01$ & $5.229 \pm 0.01$ & $5.786 \pm 0.002$ & $6.373 \pm 0.00$ & $3.772 \pm 0.02$ \\
\hline
\end{tabular}

Table 2 shows the mineral contents of I. gabonensis and $I$. wombolu leaves, peels, seeds and seed coats. The highest concentration of $\mathrm{Fe}$ in I. gabonensis was found in seed coats $(0.395 \pm 0.00 \mathrm{mg} / \mathrm{kg})$ while the lowest was found in the seeds $(0.040 \pm 0.00 \mathrm{mg} / \mathrm{kg})$. The same trend was observed in $I$. wombolu seed coats $(0.565 \pm 0.01$ $\mathrm{mg} / \mathrm{kg})$ and seeds $(0.304 \pm 0.00 \mathrm{~m} / \mathrm{kg})$. I. wombolu had a higher concentration of iron than I. gabonensis. The level of iron in this study did not agree with the work of Ujowundu et al. [21] that found low Fe in the seeds of Dacryodes eldulus but agreed with the work of Ibrahim et al. [22]. The seed is therefore recommended for eating due to its high iron content. I. wombolu contained higher concentration of sodium than I. gabonensis. The trend in the level of concentration of sodium in I. wombolu was peels $>$ seed coats $>$ leaves $>$ seeds.

For calcium, the level of concentration was higher in the seed coats $(4.912 \pm 0.01 \mathrm{mg} / \mathrm{kg})$ and lower in the seeds $(3.278 \pm 0.01 \mathrm{mg} / \mathrm{kg})$ in I. gabonensis, while in $I$. wombolu the highest concentration was in the seeds $(6.373 \pm 0.01 \mathrm{mg} / \mathrm{kg})$ and the lowest concentration was in the seed coats $(3.772 \pm 0.02 \mathrm{mg} / \mathrm{kg})$. The level of calcium in the study agreed with the work of Ujowund $\mathrm{u}$ et al. [21]. For most of the minerals determined, I. wombolu had the highest concentrations than I. gabonensis. The result of the mineral concentration in this study was lower than the work of Adeyeye [17] which had sodium $(26.2 \mathrm{mg} / \mathrm{kg})$, calcium $(35.1 \mathrm{mg} / \mathrm{kg})$ and zinc $(6.20$ $\mathrm{mg} / \mathrm{kg})$.

Mineral content in food is a measure of the amount of specific inorganic components present within the food. Minerals act as co-factors for enzyme reactions. Sodium, calcium and magnesium are required in major quantities. Sodium acts as charge carriers and is a major factor in extra cellular fluid. It also participates in the functioning of muscle nerve [23].

Table 3. Results for phytochemical screening of Irvingia gabonensis aqueous extract (AE) and methanolic extract (ME)

\begin{tabular}{|c|c|c|c|c|c|c|c|c|c|}
\hline & & \multicolumn{2}{|c|}{ Leaves } & \multicolumn{2}{|c|}{ Seeds } & \multicolumn{2}{|c|}{ Peels } & \multicolumn{2}{|c|}{ Seed coats } \\
\hline $\begin{array}{c}\text { Phyto- } \\
\text { chemicals }\end{array}$ & Tests & $\mathbf{A E}$ & ME & $\mathbf{A E}$ & ME & $\mathbf{A E}$ & ME & $\mathbf{A E}$ & ME \\
\hline \multirow[t]{2}{*}{ Alkaloids } & Wagner's test & ++ & + & + & + & - & + & - & + \\
\hline & Meyer's test & + & + & ++ & + & + & ++ & + & ++ \\
\hline \multirow[t]{2}{*}{ Flavonoids } & $\begin{array}{l}\text { Ferric } \\
\text { chloride test }\end{array}$ & ++ & + & ++ & + & + & + & ++ & ++ \\
\hline & $\begin{array}{l}10 \% \text { Lead } \\
\text { acetate test }\end{array}$ & + & ++ & - & - & + & ++ & ++ & + \\
\hline \multirow[t]{2}{*}{ Tannins } & $\begin{array}{l}5 \% \text { Lead } \\
\text { acetate test }\end{array}$ & + & + & - & - & + & + & + & + \\
\hline & $\mathrm{HCl}$ test & ++ & + & - & - & - & - & + & + \\
\hline $\begin{array}{l}\text { Cardiac } \\
\text { glycosides }\end{array}$ & $\begin{array}{l}\text { Keller } \\
\text { Killiani } \\
\end{array}$ & + & - & + & + & - & ++ & + & ++ \\
\hline Terpenoids & Salkowski & + & ++ & + & + & - & + & + & ++ \\
\hline \multirow[t]{2}{*}{ Saponins } & Water & + & + & + & + & + & ++ & Slightly + & + \\
\hline & Olive oil & + & + & + & + & + & ++ & + & + \\
\hline Steroids & Salkowski & + & - & & & ++ & - & ++ & ++ \\
\hline
\end{tabular}

(+): presence (moderate amount); (++): presence (high concentration); (-): absence.

Table 4. Results for phytochemical screening of Irvingia wombolu aqueous extract (AE) and methanolic extract (ME)

\begin{tabular}{|c|c|c|c|c|c|c|c|c|c|}
\hline \multirow[b]{2}{*}{$\begin{array}{l}\text { Phyto- } \\
\text { chemicals }\end{array}$} & \multirow[b]{2}{*}{ Tests } & \multicolumn{2}{|c|}{ Leaves } & \multicolumn{2}{|r|}{ Seeds } & \multicolumn{2}{|c|}{ Peels } & \multicolumn{2}{|c|}{ Seed coats } \\
\hline & & $\mathbf{A E}$ & ME & $\mathbf{A E}$ & ME & $\mathbf{A E}$ & ME & $\mathbf{A E}$ & ME \\
\hline \multirow[t]{2}{*}{ Alkaloids } & Wagner's test & + & + & + & + & + & + & + & + \\
\hline & Meyer's test & ++ & + & + & + & + & + & + & + \\
\hline \multirow[t]{2}{*}{ Flavonoids } & Ferric chloride test & ++ & + & + & + & + & + & + & + \\
\hline & $\begin{array}{l}10 \% \text { Lead acetate } \\
\text { test }\end{array}$ & + & + & + & - & ++ & + & Slightly + & Slightly + \\
\hline \multirow[t]{2}{*}{ Tannins } & $5 \%$ Lead acetate test & + & + & + & - & + & + & - & - \\
\hline & $\mathrm{HCl}$ test & + & + & - & - & - & + & - & - \\
\hline $\begin{array}{l}\text { Cardiac } \\
\text { glycosides }\end{array}$ & $\begin{array}{l}\text { Keller } \\
\text { Killiani }\end{array}$ & ++ & - & - & + & + & + & Slightly + & ++ \\
\hline Terpenoids & Salkowski & + & Slightly + & + & + & + & - & Slightly + & + \\
\hline Saponins & Water & + & - & + & Slightly + & ++ & ++ & ++ & + \\
\hline
\end{tabular}




\begin{tabular}{|l|l|c|c|c|c|c|c|c|c|}
\hline & & \multicolumn{2}{|c|}{ Leaves } & \multicolumn{2}{c|}{ Seeds } & \multicolumn{2}{c|}{ Peels } & \multicolumn{2}{c|}{ Seed coats } \\
\hline $\begin{array}{c}\text { Phyto- } \\
\text { chemicals }\end{array}$ & \multicolumn{1}{|c|}{ Tests } & AE & ME & AE & ME & AE & ME & AE & ME \\
\hline & Olive oil & + & + & + & + & ++ & ++ & ++ & + \\
\hline Steroids & Salkowski & & & & & ++ & - & + & + \\
\hline
\end{tabular}

Table 3 shows the phytochemical screening results of I. gabonensis while Table 4 shows that of $I$. wombolu leaves, seeds, peels and seed coats. The results revealed the presence of alkaloids, tannins, flavonoids, terpenoids, steroids, saponins and glycosides in both species of Irvingia in varying quantities. These compounds are known to be biologically active and therefore aid in the antimicrobial activities [24].

Phytochemicals like alkaloids, flavonoids, terpenoids, steroids, saponins are present in both extracts (aqueous and methanolic) of the Irvingia species studied. There are flavonoid units with several degrees of condensation [25]. The flavonoid pigments are water soluble. Flavonoid protects plants against damaging effect caused by UV-radiation and antimicrobial infection [26]. It possesses antioxidant and hormonal activity imitating human ostrogen and helps to reduce menopausal symptoms and osteoporosis, increased blood flow and oxygenation of the cells and tissue [27, 28]. Flavonoids provide beneficial effects on capillaries and absorb oxygen radicals that cause skin oxidation through their antioxidant properties. Flavonoids in general help to reverse age related declines in cognitive function by increasing the number of connections among neurons which could help prevent and treat a variety of neurogenerative disorder [29]. The peels of both species of Irvingia had high levels of saponin. The nutritional significance of saponins stems largely from their hypo cholesterolemic action, leading to the belief that they may prove useful in the control of human cardiovascular diseases [17]. Terpenoids are used traditionally for medicinal purposes and currently being explored as anti-cancer agents in clinical trials. It exhibits cyto-toxicity against a variety of tumor cells as well as anticancer efficacy in preclinical animal models [30].

\section{Conclusions}

Proximate composition of Irvingia gabonensis and Irvingia wombolu species revealed the presence of carbohydrate, crude protein, crude fiber, crude lipid and moisture in varying amount in the various parts investigated. Irvingia species are therefore considered important due to their various food components. Minerals like magnesium, sodium, calcium and zinc were available in the various parts of these two species and iron had the least concentration. The leaves of $I$. gabonensis contained the highest concentration of minerals among the parts studied while the peels of $I$. wombolu had the higher concentration of minerals. Phytochemical analysis revealed the presence of alkaloids, flavonoids, tannins, glycosides, terpenoids, saponins and steroids in both species. The presence of these phytochemicals, minerals and other food components renders the Irvingia species very valuable as food nutrients and in reduction of various disease states. The Irvingia species are therefore recommended for their nutrient value. The various parts of these species especially the leaves and peels are very valuable and should be highly recommended.

\section{Conflict of interest}

No conflict of interest declared.

\section{References}

[1]. D.J. Harris, A revision of the Irvingiaceae in Africa, Bulletin du Jardin Botanique National de Belgique 65 (1996) 143-196.

[2]. L. Matos, J.M. Nzikou, E. Matouba, V.N. Pandzou-Yembe, T.G. Mapepoulou, M. Linder, S. Desobry, Studies of Irvingia gabonensis seed kernel: oil technological applications, Pakistan Journal of Nutrition 8 (2009) 151-157.

[3]. J.I. Ngondi, J.E. Obeh, S.R. Minka, The effect of Irvingia gabonensis seeds on body weight and blood lipids of obese subjects in Cameroon, Lipids on Health and Disease 4 (2005) 12-15.

[4]. E. Etebu, A. Tungbulu, Bacterial quality of postharvest Irvingia gabonensis, International Journal of Applied Microbiology and Biotechnology Research 3 (2015) 96-103.

[5]. A.R. Atangana, Z. Tchoundjeu, J.M. Foldout, Asaah, E. Dumb, M.R.R.B Leakoy, Domestication of Irvingia gabonensis: Phenotypic variation in fruit and seed kernels in two populations from Cameroon, Agroforestry Systems 53 (2001) 55-64.

[6]. A.O. Sulaimon, T. Auta, A.T. Hassan, Evaluation of anti-diabetic activity of Irvingia gabonensis leaf and bark in alloxan induced diabetic rats, Biosciences Research Support Foundation 1 (2015) 84-89.

[7]. C.O. Okolo, Analgesic effect of Irvingia gabonensis stem bark extract, Journal of Ethno pharmacology 45 (1995) 125-129.

[8]. H.C. Okolo, Industrial potential of various Irvingia gabonensis products such as oil, ogbono and juice, ICRAF-IITA Conference on Irvingia gabonensis, Ibadan, Nigeria (1994).

[9]. O.O. Ekpe, I.B. Umoh, O.U. Eka, Effect of a typical and processing method on the proximate composition and amino acid profile of bush mango seeds (Irvingia gabonensis), African Journal of Food, Agriculture, Nutrition and Development 7 (2007) 1-12.

[10]. D.A. Fadare, E.O. Ajalyeoba, Phytochemical and antimicrobial activities of the wild mango Irvingia gabonensis extracts and fractions, African journal of medicine and medical sciences 37 (2008) 119-124.

[11]. E.T. Ayuk, B. Duguma, S. Franzel, J. Kenge, M. Mollet, P. Zenteng, Uses, management and 
economic potential of Irvingia gabonensis in the humid lowlands of Cameroon, Forest Ecology and Management 113 (1999) 1-9.

[12]. AOAC (Association of Official Analytical Chemists), Official Methods of Analysis, $20^{\text {th }} \mathrm{Ed}$. Washington DC, USA: 120 (2016).

[13]. J. Harborne, Phytochemical, Acad. Press London, vol. 21, p. 2785 (1993).

[14]. F. Abdulrahman, I.S Inyang, J. Abbah, L. Binda, S. Amos, K. Gamaniel, Effects of aqueous leaf extract of Irvingia gabonensis on gastrointestinal tract in rodents, Indian Journal of Experimental Biology 42 (2004) 787-791.

[15]. D. J. Brooker, Quality assurance for corn, wheat flour tortilla manufacturing, AACC International, Inc. Elsvier Inc. 97-123 (2005).

[16]. F.O Ekundayo, O.A. Oladipupo, E.A. Ekundayo, Studies on the effects of microbial fermentation on Bush Mango (Irvingia gabonensis) seed cotyledons, African Journal of Microbiology Research 7 (2003) 4363-4367.

[17]. I.E. Adeyeye, Proximate, mineral and antinutrient composition of Dika nuts (Irvingia gabonensis) kernel, Elixir Food Science 58 (2013) 14902-14906.

[18]. G.E. Efosa, E.E. Obosa, U. Usunomena, Proximate composition, mineral content and amino acid profile of Irvingia gabonensis O'Rorke Bail leaf, International Journal of Scientific World 5 (2017) 23-27.

[19]. K.O Soetan, C.O Olaiya, O.E Oyewole, The importance of mineral elements for humans, domestic animals and plants; a review, African Journal of Food Science 4 (2010) 200-222.

[20]. M.K. Gatar, A.U. Ifodu, F.A. Atiku, A.M. Hassan, J. Peri, Proximate, acidic mineral composition of the leaves of hairy indigo, $34^{\text {th }}$ Annual International Conference Proceedings of Chemical Society of Nigeria, pp. 19-23 (2011).

[21]. C.O. Ujowundu, F.N. Kalu, O.E. Okafor, N.C. Agha, C.S. Alisi, R.N. Nwaoguikpe, Evaluation of the chemical composition of Dacryodes edulis (G. Don) seeds, International Journal of Biological and Chemical Sciences 4 (2010) 1225-1233.
[22]. H.O. Ibrahim, O. Osilesi, O.O. Adebawo, F.D. Onajobi, K.O. Karigidi, L.B. Mohammed, Nutrients compositions and phytochemical contents of edible parts of Chrysophyllum albidum fruit, Journal of Nutrition and Food Sciences 7 (2017) 2.

[23]. N.M. Mgbemena, G.A. Obodo, A.C.I. Anusiem, C.I. Ezigbo, I. Ilechukwu, V.O. Mgbo, O. Enoo, Fundamental aspects of chemistry, M. and J. Grand Orbit Communications Port Harcourt Nigeria, pp. 67-72 (2016).

[24]. O.O Igbinosa, E.O. Igbinosa, O.A. Aiyegoro, Antimicrobial activity and phytochemical screening of stem bark extracts from Jatropha Curcas (Linn), African Journal of Pharmacy and Pharmacology 3 (2009) 058-062.

[25]. A. Ammar, L. Naoufal, B. Azam, G.W. Dennis, A.L. David, Phytochemicals: extraction, isolation and identification of bioactive compounds from plant extracts, Plants 6 (2017) 42.

[26]. D.G. Oakenfull, G.S. Sidhu, A mechanism for the hypocholesterolaemic activity of saponins, British Journal of Nutrition 55 (1986) 643-649.

[27]. M.M. Etukudo, A. Hamilton - Amachree, E.M.I Roberts, A study on mineral and proximate compositions of callus segments of Irvingia wombolu Midbr using in vitro technique, European International Journal of Science and Technology, 4 (2015) 38-46.

[28]. J.P. Spencer, Flavonoids and brain health: multiple effects underpinned by common mechanisms, Genes and Nutrition 4 (2009) 243-250.

[29]. R.J. Williams, J.P. Spencer, Flavonoids, cognition and dementia: actions, mechanisms and potential therapeutic utility for Alzheimer disease, Free Radical Biology and Medicine 52 (2012) 35-45.

[30]. Q.R. Jorres, J. Warford, H.P. Rupasinghe, G.S. Roberson, Target based selection of flavonoids for neurodegenerative disorders, Trends in Pharmacological Sciences 33 (2012) 602-610.

Received: 20.12 .2018

Received in revised form: 21.05.2019

Accepted: 25.05.2019 